\title{
EXPLORATION OF PROBLEM-POSING ABILITY OF THE STUDENTS OF CLASS VII-D OF STATE JUNIOR HIGH SCHOOL 4 KINTAMANI THROUGH MATHEMATICAL PROBLEM-BASED ETHNOMATHEMATICS
}

\author{
Jero Budi Darmayasa \\ Jurusan Pendidikan Matematika, FKIP Universitas Borneo Tarakan \\ jerosongan@gmail.com
}

\begin{abstract}
Abstrak
Penelitian ini merupakan penelitian deskriptif. Penelitian bertujuan untuk mengeksplorasi dan mendeskripsikan kemampuan Problem Posing siswa kelas VII SMPN 4 Kintamani terutama pada dimensi kreatif. Berdasarkan data yang diperoleh, diketahui bahwa siswa Kelas VII secara umum sudah mulai menunjukkan kreativitasnya dalam mengajukkan soal/pertanyaan berkaitan dengan matematika. Disamping itu, pemberian soalsoal matematika berbasis Ethnomathematics atau Mathematical Problem based Ethnomathematics (MPbE) memberikan warna tersendiri dalam diskusi kelas, karena bagi siswa merupakan hal baru. Mereka baru menyadari bahwa berbagai aktivitas agama dan budaya yang selama ini dilakukan berkaitan dan bahkan kaya dengan konsep-konsep matematika seperti yang mereka pelajari di sekolah.
\end{abstract}

Kata kunci: Ethnomathematics, PBL, Problem Posing

\begin{abstract}
This is descriptive research. The research aims to explore and describe the ability of Problem-Posing of class VII students of State Junior High School 4 Kintamani notably in the creative dimension. Based on the data obtained, it is found out that generally, Class VII students started to demonstrate their creativity in asking questions/problem related to mathematics. Moreover, by giving mathematical Problem-based Ethnomathematics (MPbE) provides its own coloring in the class discussions, for it is new to the students. They have just realized that the various religious and cultural activities that had been carried out were related to and even rich in mathematical concepts just likewhat they had learned in school.
\end{abstract}

Keywords: Ethnomathematics, Problem Based Learning, Problem Posing

Sitasi: Darmayasa, B.J. 2019. Exploration of Problem-Posing Ability of The Students of Class VII-D of State Junior High School 4 Kintamani Through Mathematical ProblemBased Ethnomathematics. Matematika dan Pembelajaran, 7(1), 102-114. 


\section{INTRODUCTION}

A human being is a social creature with the advantages of the ability to think when compared to other living things. As social beings, humans always deal with various problems. The problems dealt with shall be usually related to daily activities or anything related to other people. Often a person's competence is seen from the ability to deal with and resolve the problem. The ability to solve problems may basically be trained or educated.

Formal education is one of the places for the next generation practicing their ability to solve their problems. Various competencies are expected to be possessed by students as a provision to be able to solve the problems in daily life. Some thinking skills that can be used as provisions in solving problems such as, the ability to think logically, coherently, systematically, logarithmically, and analytically are trained through mathematics.

Taking notice that mathematics is taught, one of them, to provide provisions for students to solve problems, mathematical problems risingshall be an important part of learning mathematics, including learning mathematics in junior high school. On the other hand, every student has experienced and obtained non-formal education in the family environment. Education in the family environment is very closely related to the socio-cultural aspects of the area concerned. Therefore, basically, every student has a culture-based initial knowledge, whether related to the concepts being studied or not.

When students get the knowledge that is in contrast to aspects of the culture in which they are raised, there will be a possibility of cognitive conflict to occur in the student concerned. Therefore, adjustments or integration between the problem(s) presented in the learning process should be integrated with the culture in the environment. Integration of culture, mathematics, and technology and art is known as Ethnomathematics.

Ethnomathematics consists of three parts; Ethno + Mathema + Tics. Ethno is concerned with culture, Mathema relates to mathematical activities including explaining and understanding. Tics mean art or technique (D’Ambrosio, 1984 in 
Scott, 2011: 2). Therefore, it can be said that Ethnomathematics is an art or technique for knowing, explaining, and understanding differences in cultural contexts (D'Ambrosio, 1990). The importance of Ethnomathematics in mathematics learning is further explained by D'Ambrosio (2011) who represents Ethnomathematics as a form stating the relationship between culture and mathematics. In this case, it is explained how present-day mathematics learning and its challenges in the future tend to require students to have the ability to use technological equipment in solving problems.

Some mathematicians or mathematical experts who have an interest in mathematics present the results of their research and thinking about the role of Ethnomathematics in mathematics learning. Ethnomathematics is stated to function to express the relationship between culture and mathematics (Marsigit, 2016). Furthermore, it is stated that Ethnomathematics is only relevant for learning mathematics with the School of Mathematics domain. This is very possible for someone's mathematics is influenced by their cultural setting because what they do shall be based on what they see and feel or experience (Zusmelia, 2016).

It is even mentioned that children come to classrooms not as "tabula rasa" but are rich in collections of ideas and experiences that are shown in parts by cultural backgrounds and events in everyday life that are part of cognitive functions, both visible and popping up (Kinard \& Kozulin, 2008). Therefore learning mathematics through a relevant culture and relating to personal experience will help students to understand reality, culture, social, environmental issues, and identity understanding of themselves and guide them with mathematical content and approach that lead to academic success in mastering mathematics (Rosa \& Shirley, Introduction, 2016).

Taking into account the importance of ethnomathematics in learning mathematics, it is deemed necessary to explore ethnomathematics and use them as a basis for exploring certain competencies. In addition, as one of the ideas to minimize the distance between the past and the future can be done by collecting examples from past traditions on one side and collecting examples of technological 
results on other occasions. It will enrich students' experiences and broaden their vision in the future, as a result, students will have more understanding and they will really learn mathematics (Musse, 2015).

In Indonesia, many cultures are rich in mathematical concepts. Hartoyo's study (2012) found that ethnomathematics at a simple level is widely used by Dayak people in living their daily lives. The concept that mostly used is the concept of counting, numbering, measuring, weighing, determining the location, designing, and making symmetrical constructs. Ethnomathematics that exist in Balinese webbing crafts is the use of the principle of tessellation/tiling in woven patterns. The webbing pattern in sokasi, tempeh, bodag, lampid, capil, and bedeg uses the principle of tessellation (Puspadewi \& Putra, 2014). There is also the result of ethnomathematics exploration of Balinese people who find that the determination of otonan (birthday in Bali) uses the concept of Least common multiple (Suryanatha \& Apsari, 2013).

Ethnomathematics in the implementation may be used as a context in mathematical questions (Abdillah, 2015). In that case, Problem Based Learning or Project-based Learning is an approach that can be integrated with ethnomathematics. Gallagher, 1997; Resnick \& Klopher, 1989) in White (2001) states that In general PBL is an effective method of improving Problem-solving skills for students. Students will make stronger connections between concepts when they learn facts and skills actively with information compared to receiving information.

In addition to problem-solving, Problem Posing is an equally important competency owned by students. In its implementation in class, the problem posing is essentially asking students to pose problems or questions related to the material being studied. Silver in Silver and Cai (1996) in Siswono (2000: 1). To develop Problem Posing abilities, problem-solving becomes an important part. A condition or situation to be said as a problem or question is when the resolution of the condition cannot be found immediately (Sumarmo, 2015: 3). It is further stated that, in terms of its component composition, problems can be well-structured and ill- 
structured. The problem is called Well-Structured if all the components needed for problem-solving are available, whereas the problem is said to be Ill-Structured if to solve the problem, data, elements, or other information are needed at first (Sumarmo, 2015: 4). In the implementation, there are two views on Problem Posing, they are Accepting and Challenging. Furthermore, accepting is considered as the first phase and continues with the second phase, What if Not (Brown \& Walter, 2005: 12).

Referring to the foregoing explanation, mathematical problems based on ethnomathematics need to be conducted for learning mathematics, including in State Junior High School 4 Kintamani. As an example for developing competencies related to the concept of numbers in class VII students, there are cultural aspects, namely the determination of holidays and the determination of the implementation of Bali's Birthday (Otonan). These aspects are inherent in each student and are closely related to integer operations and Least common multiple (LCM).

But the problem is from the results of discussions with several teachers of State Junior High School 4 Kintamani and the surrounding society; it is obtained several facts relating to mathematics learning and students' understanding of local culture, as follows:

a. Student mathematics learning achievement has decreased from year by year, one of which is suspected of the influence of globalization.

b. The habit of students to study outside school hours is very minimal (the results of interviews conducted with several parents of junior high school students of class IX)

c. The ability of junior high school students to determine when the fall of the Otonan day itself is very low.

Taking into account the fact, it is necessary to explore problem posing ability of VII D students of State Junior High School 4 Kintamani through the Posing of the Mathematical Problem based Ethnomathematics (MPbE) as Ethnomathematics which will be the basis or context are the Otonan and Wewaran calculations inherent in the daily life of the 4 Kintamani Junior High School students. 


\section{METHOD}

This research is a descriptive research with case study design. Data collection was performed through observation, interview, and documentation analysis on December 2016 in State Junior High School 4 of Kintamani, Bali. As one of qualitative studies, the main instrument in this research is the researcher himself. However, to accelerate data collection process then supporting instrument was arranged in form of semi-structured interview manual. Validity of internal data using several strategies including triangulation, repeated observation, participatory research, and clarified towards researcher's bias (Creswell, 2014). The research was started by identifying ethnomathematics in the school environment. Then mapping with proper school's mathematic material and make it as a context in ethnomathematic-based mathematic question preparation. After that, continued by conducting an interview with students recommended by the teachers who they thought have interest in mathematic. Then the data was analyzed descriptively by making a field report in advance so that it results an idea of student's Problem Posing ability in learning mathematic.

\section{RESULT AN DISCUSSION}

Problem-based Learning integrated with ethnomathematics was performed in VII D class of State Junior High School 4 Kintamani. There are 36 students participating in the learning activity. The learning started by delivering the following $\mathrm{MPbE} \mathrm{1:}$

\section{$\mathrm{MPbE} 1$}

Two days ago was Pagerwesi Holiday (Buda Kliwon), then the closest tumpek day (Sanicara Kliwon) and Anggara Kasih (Anggara Kliwon) is 8 days and 18 days to go respectively.

Is the above conclusion correct? 
1) Arrange some sub-problems/sub-questions to answer the above question!

2) Arrange some problems or other questions having the same characteristic with the above argument conclusion. Then arrange some problems/questions having different characteristic with the above argument conclusion characteristic!

In MPbE 1 the mathematic concept has not explicitly appear yet. It causes most students still think about the learning related to Character Lesson subject. It can be seen from the student's question, why they have to learn character lesson?

The questions asked by students were selected which one is relate to mathematic and which one is not. Form 30 students, 8 students wrote questions related to mathematic. From the 8 students proposing questions related to mathematic, 2 of them made different questions from the others. The following is the questions proposed by the students:

1) How to calculate this problem?

2) Why is it 8 days to go, not 10 ?

3) Kuningan umanis holiday is on Sunday!

4) Why holidays in Bali are 8 days consecutively, not 10 days?

5) Why is it not 9 days to go or more?

6) Kuningan holiday is held on?

7) Was 10 days ago Sixth sasih Purnama holiday?

8) 6 day ago was saraswati holiday, then was 2 days ago Pagerwesi holiday?

From the above questions or statements it can be seen that some student are already exercising the Problem Posing Ability on Creative aspect. Observing the score giving criteria of Creative Dimension written in Sumamo (2015:17), then there are student who already getting score in Authenticity aspect.

Besides, Problem 1 above basically is MPb-E related to integer operation. The basic concept that students must have is the gap between Buda-Kliwon and Saniswara Kliwon (Tumpek) is 10 days, the gap between Buda-Kliwon and Anggara Kliwon (Anggara Kasih) is 10 days, and the gap between Saniscara-Kliwon (Tumpek) and Anggara Kliwon (Anggara Kasih) is 10 days. 
Hence, the above problem can be solved as follows:

a) Since Buda-Kliwon already passed two days ago, then the closest tumpek can be calculated by reducing 10 days with the two days already passed (10$2=8$ ). So the statement that the closest Saniscara-Kliwon (Tumpek) is 8 days to go is correct.

b) Since Buda-Kliwon is already passed two days ago, then the closest Anggara Kliwon (Anggara Kasih) can be calculated by reducing 20 days with the two days already passed (20-2=18). So the statement that the closest Anggara Kliwon (Anggara Kasih) is 18 days to go is correct.

Whereas the implicit information in MPbE above, is that: 1) Buda-Kliwon, Saniscara-Kliwon (Tumpek), and Anggara Kliwon (Anggara Kasih) are sequential pair using Sapta-Wara and Panca-Wara. Sapta-Wara consists of Redite (Sunday), Soma (Monday), Anggara (Tuesday), Buda (Wednesday), Wrespati (Thursday), Sukra (Friday), and Saniscara (Saturday). Panca-Wara consists of Umanis, Paing, Pon, Wage, and Kliwon. In a situation where student does not know the gap between Buda-Kliwon nd Saniscara-Kliwon as well as the gap between Buda-Kliwon and Anggara-Kliwon then can be calculated by using the implicit information (if known). But, if they do not know the implicit information about Sapta-Wara and Panca-Wara, the the proposal of sub-questions enable them to know. To make it easier, students can arrange a supporting table as follows:

Table 1. Sapta-Wara and Panca-Wara Matrix

\begin{tabular}{|c|c|c|c|c|c|}
\hline Sanca wara & Umanis & Paing & Pon & Wage & Kliwon \\
\hline Redite & $\begin{array}{c}\text { (Redite, } \\
\text { Umanis) }\end{array}$ & $\begin{array}{c}\text { (Redite, } \\
\text { paing) }\end{array}$ & $\begin{array}{c}\text { (Redite, } \\
\text { Pon) }\end{array}$ & $\begin{array}{c}\text { (Redite, } \\
\text { Wage) }\end{array}$ & $\begin{array}{c}\text { (Redite, } \\
\text { Kliwon) }\end{array}$ \\
\hline \multirow{2}{*}{ Soma } & $\begin{array}{c}\text { (Soma, } \\
\text { Umanis) }\end{array}$ & $\begin{array}{c}\text { (Soma, } \\
\text { paing) }\end{array}$ & (Soma, Pon) & $\begin{array}{c}\text { (Soma, } \\
\text { Wage) }\end{array}$ & $\begin{array}{c}\text { (Soma, } \\
\text { Kliwon) }\end{array}$ \\
\hline \multirow{2}{*}{ Anggara } & $\begin{array}{c}\text { (Anggara, } \\
\text { Unanis) }\end{array}$ & $\begin{array}{c}\text { (Anggara, } \\
\text { paing) }\end{array}$ & $\begin{array}{c}\text { (Anggara, } \\
\text { Pon) }\end{array}$ & $\begin{array}{c}\text { (Anggara, } \\
\text { Wage) }\end{array}$ & $\begin{array}{c}\text { (Anggara, } \\
\text { Kliwon) }\end{array}$ \\
\hline
\end{tabular}


Jero Budi Darmayasa. 2019. Eksplorasi Kemampuan Problem Posing Siswa Kelas VII-D SMP... Matematika dan Pembelajaran, 7(1),110 of 114

\begin{tabular}{|c|c|c|c|c|c|}
\hline Panca wara & Umanis & Paing & Pon & Wage & Kliwon \\
\hline Buda-Wara & $\begin{array}{c}\text { (Buda, } \\
\text { Umanis) }\end{array}$ & $\begin{array}{c}\text { (Buda, } \\
\text { paing) }\end{array}$ & (Buda, Pon) & $\begin{array}{c}\text { (Buda, } \\
\text { Wage) }\end{array}$ & $\begin{array}{c}\text { (Buda, } \\
\text { Kliwon) }\end{array}$ \\
\hline \multirow{2}{*}{ Wrespati } & $\begin{array}{c}\text { (Wrespati, } \\
\text { Umanis) }\end{array}$ & $\begin{array}{c}\text { (Wrespati, } \\
\text { paing) }\end{array}$ & $\begin{array}{c}\text { (Wrespati, } \\
\text { Pon) }\end{array}$ & $\begin{array}{c}\text { (Wrespati, } \\
\text { Wage) }\end{array}$ & $\begin{array}{c}\text { (Wrespati, } \\
\text { Kliwon) }\end{array}$ \\
\hline \multirow{2}{*}{ Sukra } & $\begin{array}{c}\text { (Sukra, } \\
\text { Umanis) }\end{array}$ & $\begin{array}{c}\text { (Sukra, } \\
\text { paing) }\end{array}$ & $\begin{array}{c}\text { (Sukra, } \\
\text { Pon) }\end{array}$ & $\begin{array}{c}\text { (Sukra, } \\
\text { Wage) }\end{array}$ & $\begin{array}{c}\text { (Sukra, } \\
\text { Kliwon) }\end{array}$ \\
\hline \multirow{2}{*}{ Saniscara } & (Saniscara, & (Saniscara, & (Saniscara, & (Saniscara & (Saniscara, \\
& Umanis) & paing) & Pon) & , Wage) & Kliwon) \\
\hline
\end{tabular}

By looking at the above matrix, students can start to break down from

Buda-Kliwon to get its distance with Saniscara-Kliwon and Anggara-Kliwon.

Table 2. Sequential pair of Sapta-Wara and Panca-Wara starting from Buda-Kliwon

\begin{tabular}{|c|l|c|l|}
\hline No & \multicolumn{1}{|c|}{$\begin{array}{c}\text { Pasangan Berurut } \\
\text { (SaptaWara, } \\
\text { PancaWara) }\end{array}$} & No & \multicolumn{1}{|c|}{$\begin{array}{c}\text { Pasangan Berurut } \\
\text { (SaptaWara, } \\
\text { PancaWara) }\end{array}$} \\
\hline 1 & (Buda, Kliwon) & 12 & (Redite, Umanis) \\
\hline 2 & (Wrespati, Umanis) & 13 & (Soma, Paing) \\
\hline 3 & (Sukra, Paing) & 14 & (Anggara, Pon) \\
\hline 4 & (Saniscara, Pon) & 15 & (Buda, Wage) \\
\hline 5 & (Redite, Wage) & 16 & (Wrespati, Kliwon) \\
\hline 6 & (Soma, Kliwon) & 17 & (Sukra, Umanis) \\
\hline 7 & (Anggara, Umanis) & 18 & (Saniscara, Paing) \\
\hline 8 & (Buda, Paing) & 19 & (Redite, Pon) \\
\hline 9 & (Wrespati, Pon) & 20 & (Soma, Wage) \\
\hline 10 & (Sukra, Wage) & 21 & (Anggara, Kliwon) \\
\hline 11 & (Saniscara, Kliwon) & 22 & (Buda, Umanis) \\
\hline
\end{tabular}


From the sequential pair table above it can be seen that the gap from BudaKliwon to Saniscara-Kliwon is 10 days, the gap from Buda-Kliwon and AnggaraKliwon is 20 days and the gap between Saniscara-Kliwon to Anggara-Kliwon.

After analyzing the student's problem posing ability through MPbE I proposal then the analysis towards problem posing ability was performed through the second problem proposal.

Through the second MPbE presented it is finally obtained a deeper picture about their problem posing ability. Whereas $\mathrm{MPbE}-2$ proposed is:

$\mathrm{MPbE}-2$

A boy held Bali Birthday (otonan) on Soma-Pon-Sinta day (Monday, 30 November 2015).

a. The closest otonan of the boy is on what date and month?

b. Is it in 2016 or 2017 ?

c. What concept is used?, include the calculation process!

Mathematical Problem Posing Task:

a. Arrange some other questions having the same meaning as the question number 1 and 2 !

b. Arrange some sub-questions (intermediate question) to answer the above question!

MPbE-2 above is related to Least Common Multiple (LCM). Basically, every student is very familiar with MPbE-2 above because they definitely celebrate a small ceremony in their home. Considered from Soma-Son-Sinta explicit information, student should get a direction in doing the calculation. That is because they are introduced to the similar Problem in Elementary School. Whereas the analog Problem is:

Andi and Dian take Swimming lesson in the same swimming pool. Andi swims every 7 days and Dian swims every 5 days. If on 30 November 2015 
they swim together for the first time

a. On what date and month they swim together again for the second time?

b. Is it in 2016 or 2017 ?

c. What concept is used?, include the calculation process!

Considering that many additional information needed to solve the above problem, then MPbE-2 meets the requirement as a Problem and not a routine mathematic problem.

From MPbE-2 it is known that students are more capable to identify problem proposed by teacher related to mathematic concept. It can be seen from the increased questions proposed related to mathematic.

There are 4 among 36 students who are capable of identifying that the mathematic concept used in determining the next Otonan celebration day using LCM concept. The other 4 students capable of identifying that the problem propose is related to mathematic concept, but do not in details that it is related to LCM. Moreover there is a student proposing a question regarding mathematic. Therefore, overall there are 9 students proposing question or statement related to mathematic.

The condition is pretty interesting because researcher does not express that they learn mathematic, but they can identify that the proposed can be solved by using mathematic. The rest, there are more students proposing question related to Hindu Religion. Even though not a few of them proposing question not related to the problem faced.

Another interesting fact is that all students proposing question or statement. It means that they have good attitude especially toward lecturer, although the lecturer is a guest (not daily teacher). Question or statement proposed by students and related to mathematic can be inventoried as follows: a) Mathematic (LCM), b) mathematic (LCM), c) Mathematic (LCM), d) Mathematic (LCM), e) Mathematic (Addition), e) Is Otonan calculated every 6 months?, f) The concept used is Mathematic (Addition), g) Mathematic, h) Mathematic $(1+1=2)$, and i) How to calculate it.

The use of Ethnomathematic which is family's and society's routine becomes 
an appeal in the effort of problem proposal by students. They feel that there is a new thing in learning mathematic and feel close to them. It is in line with research result towards High School Students of Twelfth class found that one of student's creativity occurs by making various different and correct answers in solving the problem related to daily life (Abdillah \& Mastuti, 2018).

\section{CONCLUSION}

From the finding and discussion above it can be concluded that VII class students of State Junior High School 4 Kintamani start to show their creativity in learning mathematic, especially related to Problem Posing ability of Creative dimension.

\section{REFERENCE}

Abdillah. (2015). Embedded mahtematics pada budaya ukiran khas Tana Toraja untuk Konteks Pembelajaran. Horizon Pendidikan, 10(2), 235-247.

Abdillah, \& Mastuti, A. G. (2018). Munculnya Kreativtias Siswa Akibal Ill Structured Mathematical Problem. Matematika dan Pembelajaran, 6(1), 48-59.

Brown, Stephen I \& Walter marion I. (2000). The Art of Problem Posing, 3rd Edition. USA: Lawrance Erlbaum Associates, Inc.

Creswell, J. (2014). Research Design: Qualitative, Quantitative, and Mixed Method Approaches. . Los Angeles: SAGE.

D’Ambrosio, U. (1990). Etnomatemática: Arte ou técnica de explicar e conhecer. Sao Paulo, Brazil: Editora Atica. (Translated into English as Ethnomathematics: The art or technique of explaining and knowing by ISGEm.)

D'Ambrosio, Ubiratan (2001). What is Ethnomathematics, and how can it help children in schools?. Teaching Children Mathematics, 7, 6, p.308.

Gde Rawi, I Kt Bambang. (2015). Kalender Bali Tahun 2015.

Hartoyo, Agung. (2012). Eksplorasi Etnomatematika pada Budaya Masyarakat Dayak Perbatasan Indonesia-Malaysia Kabupaten Sanggau Kalimantan Barat. Jurnal Penelitian Pendidikan Vol. 13. No. 1, April 2012 (Hal. 1423).

Jama, Musse. (2015). The Role of Ethnomathematics in Mathematics Education. Pisa (Italy).

Kinard, J. T., \& Kozulin, A. (2008). Rigorus Mathematical Thinking (Conceptual Formation in Mathematical Classroom. New York: Cambridge.

Marsigit. (2016). Pengembangan Pembelajaran Matematika Berbasis Etnomatematika. Seminar Nasional Matematika dan Pendidikan 
Matematika (pp. 1-32). Padang: STKIP PGRI Sumatera Barat.

Puspadewi, K. R., \& Putra, I. G. (2014). Etnomatematika di Balik Kerajinan Anyaman Bali. Jurnal Matematika Vol. 4 No. 2. , 80-89.

Rosa, M., \& Shirley, L. (2016). Introduction. In e. a. Milton Rosa, Current and Future Perspectives of Ethnomathematics as a Program (pp. 1-3). Hanburg: Springer.

Suryanatha, I. P., \& Apsari, R. A. (2013, 11 10). https://p4mriundiksha.wordpress.com/. Retrieved 01 10, 2016, from https://p4mriundiksha.wordpress.com/:

https://p4mriundiksha.wordpress.com/2013/11/10/etnomatematika/

Sumarmo, Utari. (2015). Mathematical Problem Posing: Rasional, Pengertian, Pembelajaran dan Pengukurannya. Bandung: Pascasarjana STKIP Siliwangi Bandung dan Pascasarjana UPI.

White, Hal. (2001). Problem-Based Learning. USA: Winter 2001 Vol 11 No 1.

Zusmelia. (2016). Matematika dalam Perspektif Indegenous People dan Indegeneous Knowledge (Kasus pada Masyarakat Matrilineal Minangkabau Sebuah Tinjauan Sosiologis). Seminar Nasional Matematika dan Pendidikan Matematika (pp. 1-12). Padang: STKIP PGRI Sumatera Barat. 